\title{
Morphology and anatomy of the developing fruit of Maclura tinctoria, Moraceae ${ }^{1}$
}

\author{
SAYURI DE OLIVEIRA OYAMA ${ }^{2,3}$ and LUIZ ANTONIO DE SOUZA ${ }^{2}$
}

(received: July 7, 2010; accepted: May 2, 2011)

\begin{abstract}
Morphology and anatomy of the developing fruit of Maclura tinctoria, Moraceae). Maclura tinctoria (L.) D. Don ex Steudel was selected for the present study due of its economic and medicinal importance. The purpose of this investigation is to present a detailed description of the fruit development, specially by: (a) defining the fruit type presented by the species, and (b) characterizing the seed type of the species based upon the presence or not of mechanical tissue on the seed-coat. The fruit originates from the subglobose female inflorescence which consists of small unipistillate flowers with superior ovary, unilocular and uniovular apical placentation. The mature fruit is multiple, constituted of small drupes. The ovule is ana-campylotropous, suspended, bitegmic and crassinucellate. The mature seed is flattened, slightly ovated, cream colored, with unspecialized membrane coat with thin-walled cells more or less crushed. The seed has parenchymatic endosperm with lipophilic content. The embryo is straight, with two cotyledons of the same size. Ontogenetic studies reveal that the fruits are infrutescences. The fleshy edible part is derived from the perigone and inflorescence axis. The drupes consist of a single pyrene of macrosclereids.
\end{abstract}

Key words - drupe, embryo, integument, pericarp, perigone

RESUMO - (Morfologia e anatomia do fruto em desenvolvimento de Maclura tinctoria, Moraceae). Maclura tinctoria (L.) D. Don ex Steudel foi selecionada para estudo por sua importância medicinal e econômica. O objetivo desta investigação foi apresentar uma descrição detalhada do fruto em desenvolvimento, especialmente: (a) definir o tipo de fruto apresentado pela espécie e (b) caracterizar o tipo de semente da espécie baseado na presença ou não de tecido mecânico no tegumento. $\mathrm{O}$ fruto provém de inflorescência feminina subglobosa, que consiste de flores diminutas, unipistiladas, com ovário súpero, placentação apical, unilocular e uniovulado. O fruto maduro é múltiplo, composto por diminutas drupas. O óvulo é anacampilótropo, pêndulo, bitegumentado e crassinucelado. A semente madura é achatada lateralmente, ligeiramente ovalada, de coloração creme, com tegumento não especializado, membranáceo, com células mais ou menos comprimidas de paredes finas. A semente apresenta endosperma parenquimático com conteúdo de natureza lipofílica. O embrião é reto com dois cotilédones de mesmo tamanho. Os estudos ontogenéticos revelam que os frutos são infrutescências. A parte carnosa e comestível do fruto é formada pelo perigônio e eixo da inflorescência. As drupas consistem de um único pirênio de macrosclereídes.

Palavras-chave - drupa, embrião, pericarpo, perigônio, tegumento

\section{Introduction}

Moraceae presents approximately 1,500 species distributed in tropical, subtropical and temperate regions (Cronquist 1981, Judd et al. 2002, Souza \& Lorenzi 2005). According to Spjut (1994), the family may present different types of fruits as pseudodrupe - an anthocarpous fruit with an undifferentiated indurate pericarp surrounded by a fleshy or coriaceous exocarp; sorosus - a compound fruit composed of many succulent pericarpia that develop on a peduncle; syconium - a

\footnotetext{
1. Part of the first author's master's degree, Postgraduate Program in Comparative Biology of Universidade Estadual de Maringá, PR, Brazil.

2. Universidade Estadual de Maringá, Centro de Ciências Biológicas, Departamento de Biologia, Av. Colombo 5790, 87020-900 Maringá, PR, Brazil.

3._Corresponding author: sa_oyama@hotmail.com
}

compound fruit constituted of fruitlets enclosed in a receptacle or peduncle; and trymosum - a compound fruit consisting of pericarpia that develop within united bracts or a receptacle.

Moraceae frequently presents compound fruits that may be polycarpic or monocarpic infrutescences (Barroso et al. 1999). In the compound fruit fruitlets may be present as nutlets (Barroso et al. 1999), drupes or achenes (Judd et al. 2002, Souza \& Lorenzi 2005).

The fruit classification of the Moraceae varies according to the viewpoints of the author. Frequently the authors are inclined to show fruit classification without a good understanding of its ontogeny. For example, the fruit of Sorocea A. St.-Hil. may be regarded as a monocarpic infrutescence with nutlet enclosed by persistent and fleshy perianth (Barroso et al. 1999), but the ontogeny of the fruit of Sorocea bonplandii (Baill.) 
Burger, Lanjow \& Bôer shows that it is of pomaceous type (Souza \& Rosa 2005). This pomaceous fruit is formed by a small perianth/perigone with hypanthium representing an important part of the fruit, devoid of nutlet.

The ontogeny of seeds of the Moraceae has not yet been extensively studied. Corner (1976) has failed to find any definite structure in the seed-coats which, at most, are slightly exotestal, and he considered that the so-called seeds of this family are pyrenes. Seeds of Sorocea bonplandii were considered exotestal, based in the presence of thick-walled cells located in the raphe region (Souza \& Rosa 2005).

Maclura Nutt., including Maclura tinctoria (L.) D. Don ex Steud., may be regarded as a compound or multiple fruit with fruitlets: achene (Judd et al. 2002), nutlet (Barroso et al. 1999, Battilani et al. 2006, Martins 2009), or drupe (Martins 2009). The morphology of Moraceae fruits/seeds has been extensively studied, but the lack of any general agreement in the classification and interpretation of fruits/seeds indicates that evidently more structural investigation is needed as a fundamental approach to the problem. Therefore, the present study aims at contributing with the nomenclature and concepts used in fruits and seeds of Moraceae and to carry out a morphological and anatomical analysis of the pericarp and seed in the development of Maclura tinctoria, especially: (a) to define the fruit type presented by the species, and (b) to characterize the seed type based on the presence or absence of mechanical tissue in the seed-coat. This species occurs in forest remnants of northwestern Paraná State, Brazil, a vast region with less than $1 \%$ of the native forest cover.

\section{Material and methods}

Flower buds, flowers and fruits of different developmental stages from two specimens were collected at Parque do Ingá $\left(23^{\circ} 42^{\prime} 50.74^{\prime \prime} \mathrm{S} / 51^{\circ} 93^{\prime} 27.68^{\prime \prime} \mathrm{O}\right)$ and Reserva Florestal II $\left(23^{\circ} 25^{\prime} 57.57^{\prime \prime} \mathrm{S} / 51^{\circ} 56^{\prime} 44.38^{\prime \prime} \mathrm{O}\right)$ which are forest remnants of Maringá (state of Paraná), Brazil. Both forest remnants is under severe human action, few species of economical, medicinal and ecological importance remaining. Voucher materials were deposited at the Universidade Estadual de Maringá Herbarium (HUEM16499).

The samples were fixed in $1 \%$ glutaraldehyde (Kraus \& Arduin 1997) and later transferred to $70 \%$ ethanol (Johansen 1940). The conserved samples were dehydrated in an ethanol series. The cross and longitudinal sections were cut from historesin embedded flowers and fruits (Gerrits 1991 ) with a rotation microtome and were stained with $0.1 \%$ toluidine blue for one minute (O'Brien et al. 1964).
Developing fruits were also analyzed in freehand sections stained with astra blue and safranin (Souza et al. 2005). The structural analysis of the developing fruits and seeds was done according to Corner (1976), Roth (1977), Paoli (2006) and Souza (2006).

Specific microchemical tests were carried out for lipophilic substances (Sudan IV) (Rawlins \& Takahashi 1952), starch (iodine-potassium iodide test) (Berlyn \& Miksche, 1976), lignin (phloroglucin test) (Berlyn \& Miksche, 1976), and calcium oxalate crystals (sulphuric acid) (Sass 1951).

Morphological aspects were illustrated with the aid of a camera lucida. Anatomical illustrations were prepared using an optical microscope (Wild M20) equipped with a reflex camera. Photomicrographs were taken by processing the image captured in an Olympus microscope with a Canon Power Shot A95 digital camera using the Zoom Browser EX 4.6 software. All samples were prepared under the same micrometric scale.

Micromorphological analysis (Bozzola \& Russel 1992) was carried out with fixed material (inflorescence axis, flower and fruit). After washing in $0.1 \mathrm{M}$ sodium cacodylate buffer, the samples were dehydrated in a graded acetone series, critical point dried with $\mathrm{CO}_{2}$ (Bal-tec CPI 030 - Critical Point Dryer), and then mounted on aluminum stubs, gold coated (Shimadzu IC-50 Ion Coater), and subsequently examined using scanning electron microscopy (Shimadzu SS-550 Superscan), from which digital images were obtained.

\section{Results}

Developing fruit - Fruit arises in subglobulose inflorescence (figure 1) which consists of small female flowers. Each flower presents 6-8 green tepals and a pistil with uniloculate ovary and long style/stigma. The ovary has only one ovule with apical placentation. The ripe fruit (figure 2) is multiple with persistent perigone (figure 3).

The inflorescence axis consists of epidermis of a single layer of cells and unicellular nonglandular trichomes with tapering end (figures 4, 5), and parenchymatic and collenchymatic cortex. The central cylinder presents primary and secondary vascular tissues and parenchymatic pith (figures 4, 6). Laticifers occur in the cortex and phloem (figure 6).

The perigone epidermis of the abaxial face is composed of shortly elongated thin-walled cells (figures $7,8)$ glabrous in the base and trichomatous in the apex. The trichomes are nonglandular, unicellular and show pointed end. The heterogeneous multilayered mesophyll consists of two types of parenchyma: the adaxial one with tangentially elongated cells and the abaxial with isodiametric or slightly elongated cells (figure 8). Laticifers and cells with calcium oxalate druse occur 


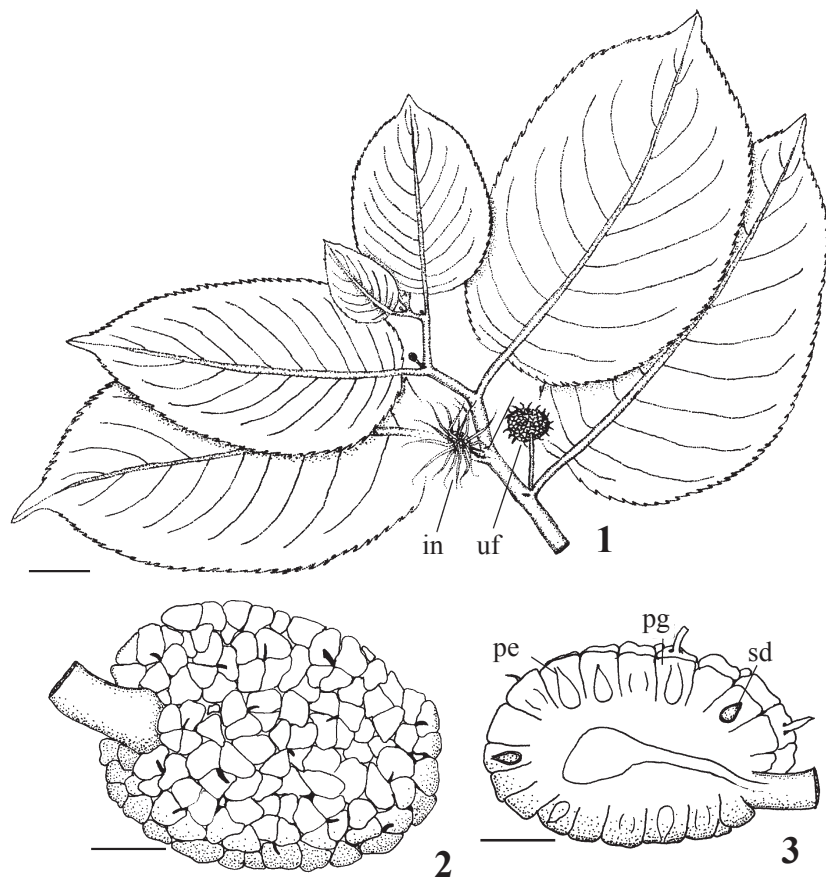

Figures 1-3. Inflorescence and fruit morphology of Maclura tinctoria. 1. Branch with inflorescence and fruit in development. 2. Ripe fruit. 3. Diagram of mature fruit in longitudinal section. (in = inflorescence; $p e=$ pericarp; $\mathrm{pg}=$ perigone; $\mathrm{sd}=$ seed; $\mathrm{uf}=$ unripe fruit). $\mathrm{Bar}=2 \mathrm{~cm}(1)$, $1 \mathrm{~cm}(2,3)$.

in the mesophyll (figures 7, 8). Unlike in the epidermis of abaxial face, neither stomata nor trichomes are seen in the epidermis of the adaxial face; in this face the epidermal cells are cuboidal or slightly elongated (figure 7). The perigone vascularization is composed by a large bundle (midrib) and small lateral bundles.

The ovary wall in cross-section (figure 9) presents epidermis glabrous with cuboidal or slightly elongated cells in both faces (figure 10); in contrast, the cells of the outer surface are tangentially elongated in longitudinal section. The mesophyll (figure 10) consists of homogeneous and multilayered (4-12 layers) parenchyma in transverse view in which cells are nearly isodiametric; elongated cells occur lying below the outer face in longitudinal section. The ovary wall presents a collateral bundle (figures 9, 12) and an amphicribral bundle (figures 9, 11) which vascularize the ovule (figures 11, 12).

In the unripe fruit, the persistent perigone exhibits remarkable structural change. Anticlinal divisions are predominant in the epidermis and periclinal divisions occur in the cell layers lying below both adaxial and abaxial faces (figure 13). In contrast to perigone, the degree of cell wall thickness and cuticle layer of the

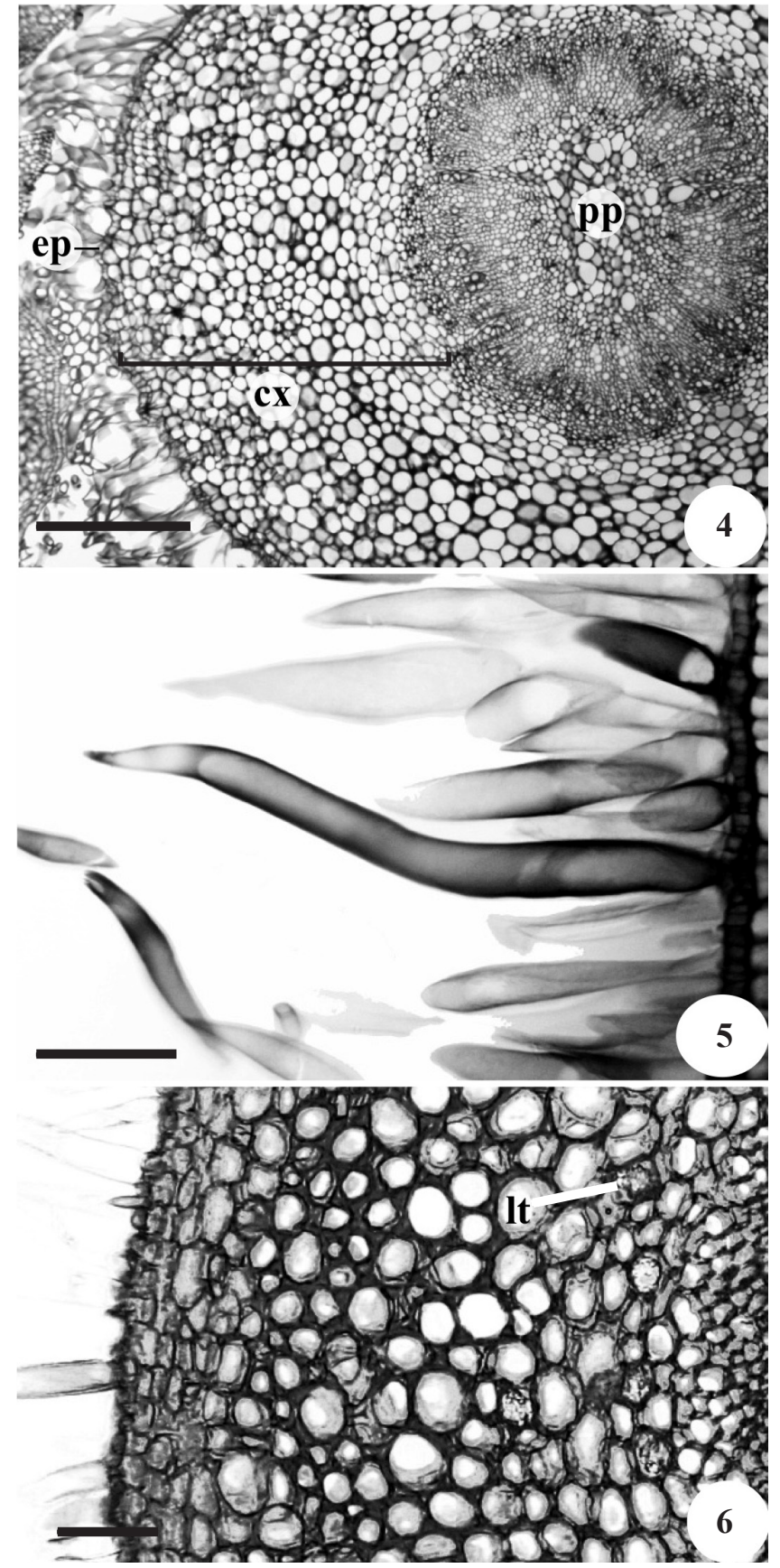

Figures 4-6. 4. Inflorescence axis of Maclura tinctoria in cross-section. 5. Trichomes in detail. 6. Epidermis/cortex. $(\mathrm{cx}=$ cortex; $\mathrm{ep}=$ epidermis lt $=$ laticifers; $\mathrm{pp}=$ parenchymatous pith). Bar $=100 \mu \mathrm{m}(4,6), 50 \mu \mathrm{m}(5)$.

unripe fruit is somewhat remarkable. The significant structural changes occur in the mesophyll with the increase of the number and size of the parenchymatic cells and laticifers (figure 14).

The unripe pericarp is originated from the ovary wall and consists of glabrous exocarp covered by a cuticle and a thick cuticular layer, and collenchymatic 

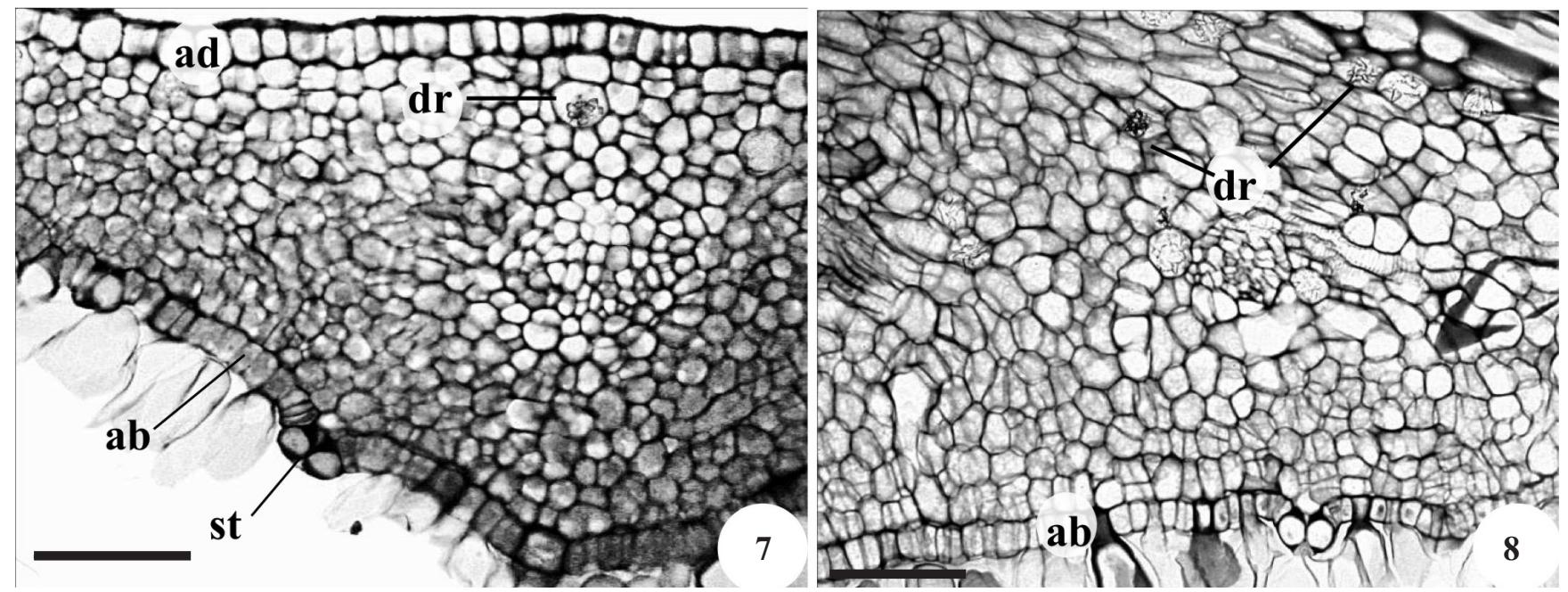

Figures 7-8. Perigone of Maclura tinctoria in cross- and longitudinal sections. $(\mathrm{ab}=$ epidermis in the abaxial face; $a d=$ epidermis in the adaxial face; $\mathrm{dr}=$ druse; $\mathrm{st}=$ stoma). $\mathrm{Bar}=50 \mu \mathrm{m}$.

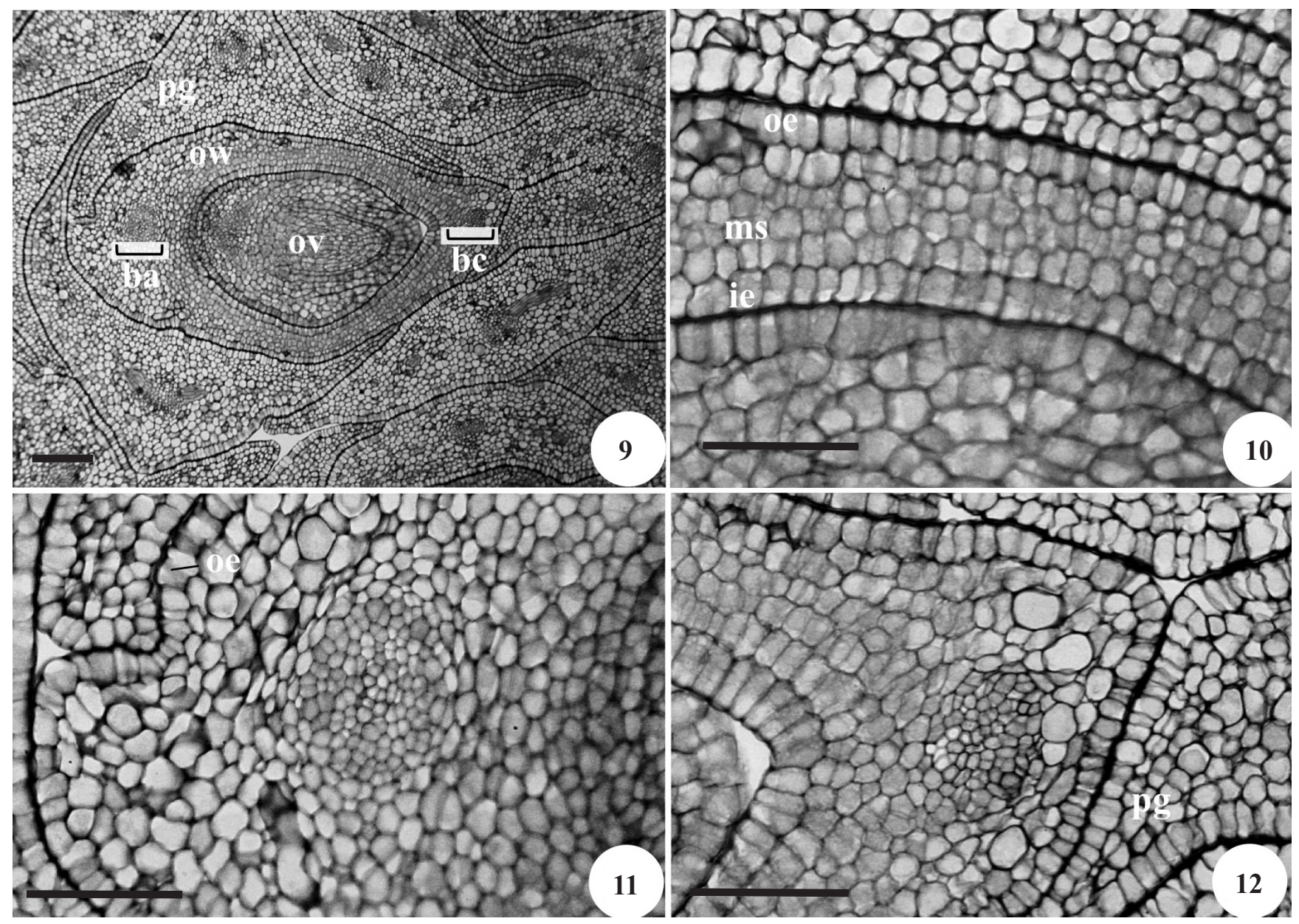

Figures 9-12. Flower structure of Maclura tinctoria, in cross-section. 9. Overview of perigone and ovary. 10. Detail of the ovary wall. 11, 12. Details of regions of the ovary showing amphicribral and collateral vascular bundles. (ba $=$ amphicribal vascular bundles; bc = collateral vascular bundles; ie = inner epidermis; $\mathrm{ms}=$ mesophyll; oe = outer epidermis; ov = ovule; ow $=$ ovary wall; pg = perigone). $\operatorname{Bar}=200 \mu \mathrm{m}(9), 50 \mu \mathrm{m}(10,11,12)$. 
mesocarp (figures 14, 15, 17). The innermost layer cells of the mesocarp, abutting on the endocarp, contain calcium oxalate crystals (figures 14, 15, 16, 17); in the parenchymatic mesocarp, laticifers still occur (figures 15,17$)$. The young endocarp is composed by the inner epidermis with radially elongated cells which differentiate into macrosclereids (figures 14, 15, 17). The macrosclereid differentiation occurs initially in the placenta region and extends basipetally towards the other extremity of the seed.
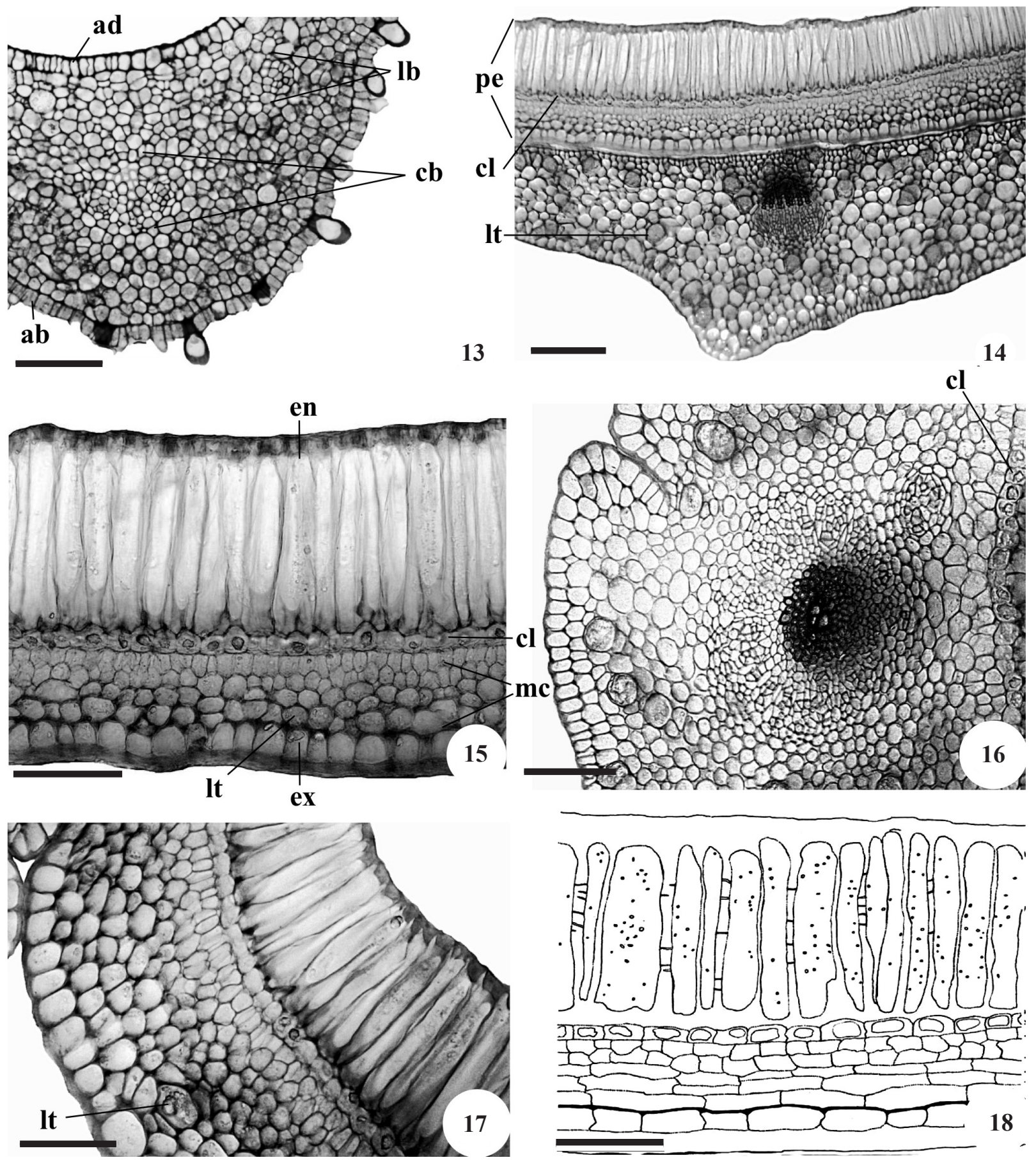

Figures 13-18. Structure of developing fruits (13-17) and ripe fruit (18) of Maclura tinctoria, in cross-section. 13. Perigone. 14. Perigone and pericarp. 15. Pericarp. 16. Placentary region with amphicribral bundle. 17. Pericarp section made near the placental region. 18. Pericarp. $(\mathrm{ab}=$ epidermis abaxial face; $\mathrm{ad}=$ epidermis adaxial face; $\mathrm{cb}=$ central vascular bundle; $\mathrm{cl}=\mathrm{crystal}$ layer; en = endocarp; $\mathrm{ex}=$ exocarp; $\mathrm{lb}=$ lateral vascular bundle; $\mathrm{lt}=$ laticifers; $\mathrm{mc}=$ mesocarp; pe $=$ pericarp). $\mathrm{Bar}=50 \mu \mathrm{m}$ $(13,15,16,17,18), 100 \mu \mathrm{m}(14)$. 
In the ripe fruit the persistent perigone is green with succulent consistence and presents uniseriate epidermis in both surfaces. Trichomes only occur in the apical region of the perigone. The mesophyll consists of parenchyma in which cells vary in size and shape. Laticifers occur scattered in the mesophyll parenchyma.

The ripe exocarp and mesocarp (figure 18) do not show significant differences in relation to the unripe pericarp. The endocarp is composed of one layer of macrosclereids which have a palisade-like appearance; their walls are thickened, lignified and have simple pits.

Developing seed - Ovule (figures 19, 20) is ana-campylotropous, pendulus, bitegmic, crassinucellate with short funicle. The vascular supply of the funiculus terminates blindly in the chalazal region. The outer integument consists of five cell-layers and the inner integument presents three cell-layers. The tip of outer integument has more than three cell-layers. The nucellus is parenchymatic with small, polyhedral, thin-walled cells.

In the developing seed (figure 21) the testa maintains the same number of cell layers as the outer integument of the ovule. The tegmen is crushed. The endosperm is nuclear and consists of thin-walled cells.

The ripe seed (figures 22, 23) is small, exarillate, laterally compressed, slightly ovalate, with smooth and cream seedcoat. The testa (figures 24, 25) is membranous, more or less crushed, with thin-walled cells. The endosperm is parenchymatous and oily. The embryo (figure 26) is straight with two cotyledons of the same size. Vascular supply occurs in the raphe only and the vascular bundle is amphicribral.

\section{Discussion}

In the literature, different denominations for the types of fruits that occur in Moraceae were registered as infrutescences or multiple fruits (Roth 1977), and compound fruits (Spjut 1994, Barroso et al. 1999). In Maclura (synonyme Chlorophora Gaudich.) there is also a divergence of classification of fruits, registering the sorosus type (Spjut 1994) and the compound fruit with nutlets (Barroso et al. 1999). The fruit of Maclura tinctoria originates from a globose, green and fleshy inflorescence and was classified as a multiple one, in agreement with Roth (1977) and Souza (2006).

Dispersal units which are composed of several to many flowers and originate from an inflorescence are

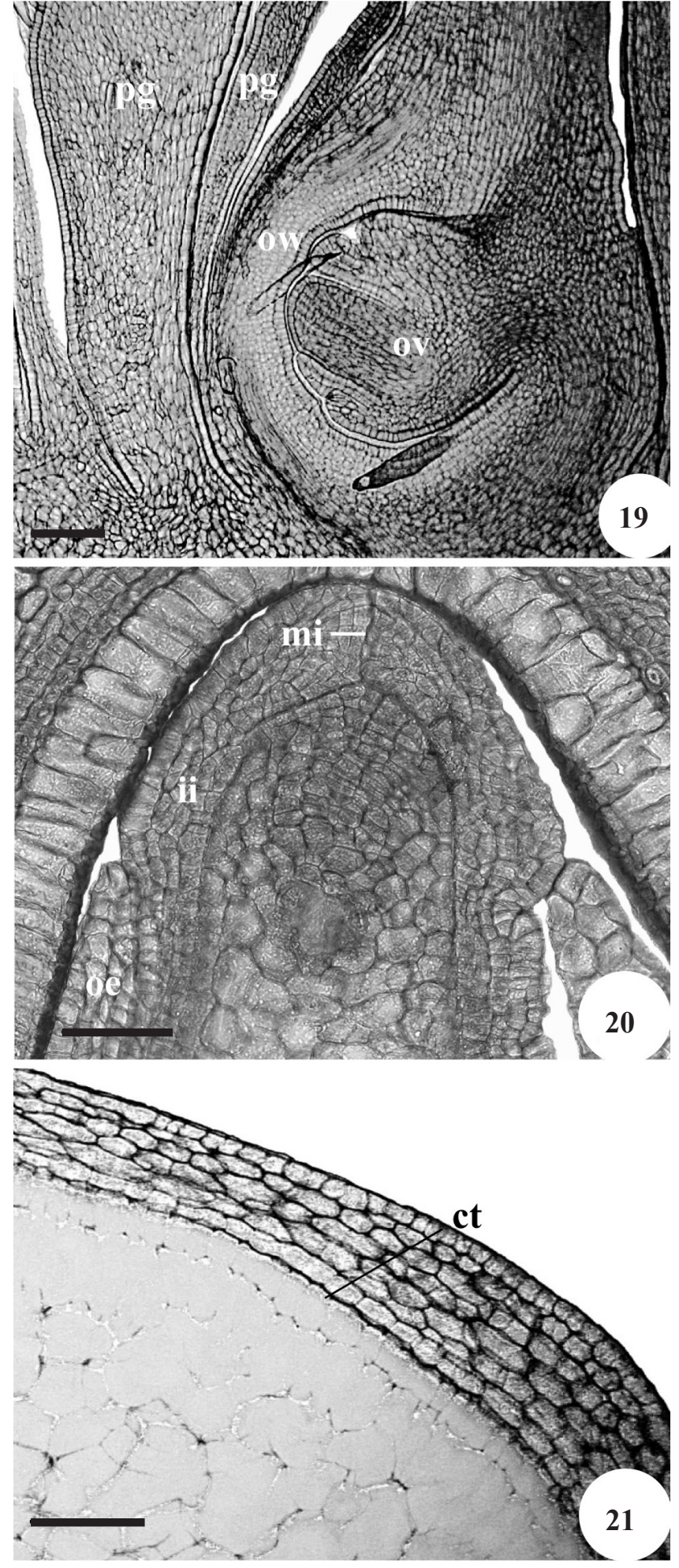

Figures 19-21. Ovule and developing seed structures of Maclura tinctoria, in longitudinal section $(19,20)$ and cross-section (21). 19, 20. Flower sections showing ovules in different stages of development. 21. Integument and nucellus. $(\mathrm{ct}=$ cuticle $; \mathrm{ii}=$ inner integument $; \mathrm{mi}=$ micropyle; oe $=$ outer integument; ov $=$ ovule; ow $=$ ovary wall; $\mathrm{pg}=$ perigone) . Bar $=100 \mu \mathrm{m}(19,20), 50 \mu \mathrm{m}(21)$. 

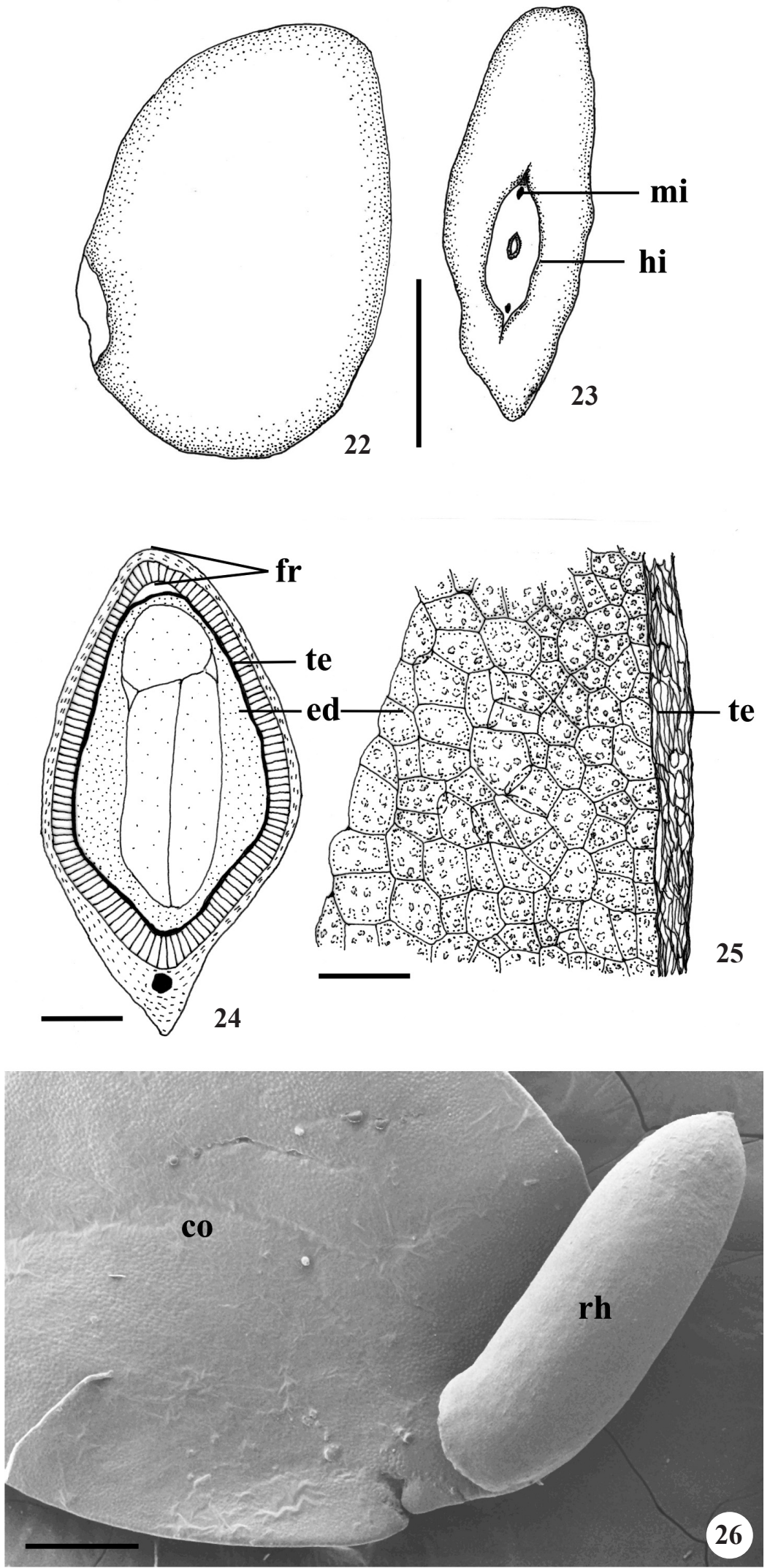

Figures 22-26. Seed and embryo morphology of Maclura tinctoria. 22, 23. Ripe seed in side and front views. 24. Diagram of fruit with seed. 25. Integument and endosperm. 26. Embryo. (co = cotyledon; ed = endosperm; fr = fruit; hi = hilo; $\mathrm{mi}=$ micropyle; $\mathrm{rh}=$ radicle-hypocotyl axis; te = testa). Bar $=50 \mu \mathrm{m}(25), 100 \mu \mathrm{m}(24), 500 \mu \mathrm{m}(26), 1 \mathrm{~mm}(22,23)$. 
relatively rare (Roth 1977), but they occur frequently in Moraceae and Maclura tinctoria, which present fleshy and edible perigone. The Maclura tinctoria multiple fruits are eaten by birds (Rodrigues et al. 2007) and monkeys (bugio) (Aguiar et al. 2003).

There are diverging opinions regarding the fruitlet type of the multiple fruit in Maclura, such as nutlets (Barroso et al. 1999), achenes (Judd et al. 2002) and drupes (Martins 2009). A study of the developmental fruit in Maclura tinctoria shows that the fruitlets are drupes consisting of epicarp and mesocarp fleshy and of stone or pyrene that encloses one seed. The pyrene of Maclura tinctoria is derived from the inner epidermis of the ovary that differentiates into macrosclereids layer, as registered by Lauraceae (Souza \& Moscheta 2000) and Cordia trichotoma (Vell.) Arrab. ex I. M. Johnst, Boraginaceae (Souza 2008). The pyrene may also be multilayered and it may arise only from the inner epidermis and/or subepidermal layer of the ovary wall (Roth 1977, Souza 2006, Souza et al. 2008). Jacomassi et al. (2010) registered sclerenchymatic multilayered pyrene in Brosimum gaudichaudii Trécul (Moraceae) without the definition of the fruit type. On the other hand, the pyrene was not found in Sorocea bonplandii (Moraceae), in which the fruit was classified as pomaceous type (Souza \& Rosa 2005).

In a comparative study of several monocarpellary drupes of Rosaceae, Kaniewsky (1963) observed that the differentiation of the sclerenchymatic endocarp takes place first in the placentary region and then continues on the remaining pericarp. The radial elongation, wall thickening and lignification of the endocarp macrosclereids of Maclura tinctoria occur in a similar way.

As crystals are often found in the vicinity of sclerenchymatic cells, a crystal layer frequently accompanies the endocarp (Roth 1977). Maclura tinctoria also presents monocrystals in the subendocarpic layer with unknown function. Roth (1977) suggests that the regular disposition of calcium crystals in the pericarp could have taxonomical importance. On the other hand, Franceschi \& Nakata (2005) regard that the crystal functions in plants include calcium regulation, plant protection, detoxification (e.g., heavy metals or oxalic acid), ion balance, tissue support/plant rigidity, and even light gathering and reflexion; according to the authors, there is solid evidence for the three first functions.

The structural characterization of the seed-coat ontogenesis of Maclura tinctoria allowed to record most of the characters previously described for
Moraceae (Corner 1976): testa mostly membranous, not multiplicative, thin-walled, more or less crushed; tegmen also crushed and unspecialized; embryo protection made by pyrene. Seeds with unspecialized seed-coat occur in indehiscent fruits of Aceraceae, Anacardiaceae, Cornaceae, Menispermaceae, Apiaceae and Moraceae (Paoli 2006). The seeds of Sorocea bonplandii (Souza \& Rosa 2005) and Maclura tinctoria are similar, but the former has an exception presenting thick-walled cells in the raphe.

The straight embryo of Maclura tinctoria diverges from the curved embryo found in other species of Moraceae, as Sorocea bonplandii (Souza \& Rosa 2005), Broussonetia papyrifera (L.) Vent., Cudrania tricuspidata Bureau and Maclura pomifera (Martin 1946).

Laticifers occur throughout the whole multiple fruit of Maclura tinctoria, being more abundant in the fleshy perigone. In Maclura the laticifers are nonarticulated and branched, forming an even more extensive network (Mauseth 1988, Evert 2006). Secreted substances, such as the latex, may change their consistence and composition during ripening; in ripe fruits the latex loses water and is brittle, lying in the center of the cell withdrawn from the walls (Roth 1977).

The fruits of Maclura tinctoria are infrutescences in which the perigone leaves and axis transform into the fleshy edible part. The fruitlets are drupes that are characterized by the presence of a single pyrene of macrosclereids. The seeds present unspecialized seedcoat and the embryo is protected by the pyrene.

Acknowledgements - The authors would like to thank Coordenação de Aperfeiçoamento de Pessoal de Nível Superior (Capes), and Conselho Nacional de Desenvolvimento Científico e Tecnológico (CNPq) for financial support (Master's Degree grant to S.O. Oyama and Research grant to L.A. Souza, respectively) and Dr. Sergio Romaniuc Neto (Instituto de Botânica de São Paulo) for the species identification.

\section{References}

AGUIAR, L.M., REIS, N.R., LUDWIG, G. \& ROCHA, V.J. 2003. Dieta, área de vida, vocalizações e estimativas populacionais de Alouatta guariba em um remanescente florestal no norte do estado do Paraná. Neotropical Primates 11:78-86.

BARroso, G.M., MORIM, M.P., PEIXOTO, A.L. \& ICHASO, C.L.F. 1999. Frutos e sementes - morfologia aplicada à sistemática de dicotiledôneas. Universidade Federal de Viçosa, Viçosa. 
BATTILANI, J.L., SANTIAGO, E.F. \& SOUZA, A.L.T. 2006. Morfologia de frutos, sementes e desenvolvimento de plântulas e plantas jovens de Maclura tinctoria (L.) D. Don ex Steud. (Moraceae). Acta Botanica Brasilica 20:581-589.

BERLYN, G.P. \& MIKSCHE, J.P. 1976. Botanical microtechnique and citochemistry. The Iowa State University Press, Ames.

BOZZOLA, J.J. \& RUSSELL, L.D. 1992. Electron microscopy. Jones and Bartlett Publishers, Boston.

CORNER, E.J.H. 1976. The seeds of dicotyledons. Cambridge University Press, Cambridge.

CRONQUIST, A. 1981. An integrated system of classification of flowering plants with a new foreword by Armen Takhtajan. Columbia University Press, New York.

EVERT, R.F. 2006. Esau's plant anatomy (meristems, cells, and tissues of the plant body: their structure, function, and development). John Wiley \& Sons, Hoboken.

FRANCESCHI, V.R. \& NAKATA, P.A. 2005. Calcium oxalate in plants: formation and function. Annual Review of Plant Biology 56:41-71.

GERRITS, P.O. 1991. The application of glycol methacrylate in histotechnology; some fundamental principles. Departament of Anatomy and Embriology State University, Gröningen.

JACOMASSI, E., MOSCHETA, I.S. \& MACHADO, S.R. 2010. Morfoanatomia e histoquímica de órgãos reprodutivos de Brosimum gaudichaudii (Moraceae). Revista Brasileira de Botânica 33:115-129.

JOHANSEN, D.A. 1940. Plant microtechnique. McGrawHill Book Company, New York.

JUDD, W.S., CAMPBELL, C.S., KELLOGG, E.A., STEVENS, P.F. \& DONOGHUE, M.J. 2002. Plant systematics - A phylogenetic approach. $2^{\text {nd }} e d$., Sinauer Associates, Sunderland.

KANIEWSKY, K. 1963. Comparative investigations on the development of the endocarp of different species of drupaceous fruits. Rocznik Dendrologiczny 17:5-45.

MARTIN, A.C. 1946. The comparative internal morphology of seeds. American Midland Naturalist 36:513-660.

MARTINS, E.G.A. 2009. O clado Urticoide (Rosales) na flora da Serra do Cipó, Minas Gerais. Dissertação de mestrado, Universidade de São Paulo, São Paulo.

MAUSETH, J.D. 1988. Plant anatomy. The Benjamin/ Cummings Publishing Company, Menlo Park.

O'BRIEN, T.P., FEDER, N. \& MCCULLY, M.E. 1964. Polychromatic staining of plant cell walls by toluidine blue O. Protoplasma 59:368-373.
PAOLI, A.A.S. 2006. Semente. In Anatomia do fruto e da semente (L.A. Souza, org.). Editora Universidade Estadual de Ponta Grossa, Ponta Grossa, p.126-163.

RAWLINS, T.E. \& TAKAHASHI, W.N. 1952. Technics of plant histochemistry and virology. The National Press, Millbrae.

RODRIGUES, S., CAETANO, D.G. \& CAETANO, C.M. 2007. Espécies frutíferas do centro-sul do Estado de Rondônia, Amazônia brasileira. Acta Agronómica 56:69-74.

ROTH, I. 1977. Fruits of angiosperms. In Encyclopedia of plant anatomy (K. Linsbauer, F.G. Tischler \& A. Pascher, eds.). Gebrüder Borntraeger, Berlin, p.557-564.

SASS, J.E. 1951. Botanical microtechnique. Iowa State College Press, Iowa.

SOUZA, L.A. 2006. Fruto. In Anatomia do fruto e da semente (L.A. Souza, org.). Universidade Estadual de Ponta Grossa, Ponta Grossa, p.10-123.

SOUZA, L.A. 2008. Morphology and anatomy of the Cordia trichotoma (Vell.) Arrab. ex I.M. Johnst. diaspore (Boraginaceae). Brazilian Archives of Biology and Technology 51:761-768.

SOUZA, L.A. \& MOSCHETA I.S. 2000. Morfo-anatomia do desenvolvimento do fruto de Ocotea puberula (Rich.) Nees e de Nectandra megapotamica (Spreng.) Mez (Lauraceae). Acta Científica Venezolana 51: 84-89.

SOUZA, L.A. \& ROSA, S.M. 2005. Morfo-anatomia do fruto em desenvolvimento de Sorocea bonplandii (Baill.) Burger, Lanjow \& Boer (Moraceae). Acta Scientiarum, Biological Science 27:423-428.

SOUZA, L.A., ROSA, S.M. \& MOSCHETA, I.S. 2008. Anatomy of the developing fruit of Metrodorea nigra A. St.-Hil. (Rutaceae). Brazilian Archives of Biology and Technology 51:1171-1179.

SOUZA, L.A., ROSA, S.M., MOSCHETA, I.S., MOURÃO, K.S.M., RODELLA, R.A., ROCHA, D.C. \& LOLIS, M.I.G.A. 2005. Morfologia e anatomia vegetal-técnicas e práticas. Universidade Estadual de Ponta Grossa, Ponta Grossa.

SOUZA, V.C. \& LORENZI, H. 2005. Botânica sistemática - guia ilustrado para identificação das famílias de Angiospermas da flora brasileira, baseado em APG II. Instituto Plantarum de Estudos da Flora, Nova Odessa.

SPJUT, R.W. 1994. A systematic treatment of fruit types. Memoirs of the New York Botanical Garden 70: 1-182. 
